Vol. 2, No. 1, July 2021, Page. 21 - 30

\title{
The Effect of Self Ability, Compensation, and Self Efficacy on Employee Performance at Rizqy Jaya Mulia Sidoarjo Company
}

\author{
Abellia Permatasari ${ }^{1}$, Siti Mujanah ${ }^{2 *}$ First Author $^{1^{*}}$ \\ 1,2Faculty of Economics and Business, University of 17 gustus 1945 Surabaya \\ e-mail: sitimujanah@untag-sby.ac.id ${ }^{2}$ \\ * Corresponding Author: E-mail: sitimujanah@untag-sby.ac.id
}



\section{Introduction}

Human resources have an important meaning for the company because humans have an active and dominant function in every activity of the organization. According to Anwar Prabu Mangkunegara in Subekhi (2012:21), said that HRM is planning, organizing, coordinating, implementing, and supervising the procurement, development and separation of workers in order to achieve organizational goals (Karya, et. al. 2020). Companies must have smart strategies starting from paying attention to the vision, mission, goals to goals that must be understood by each member in the organization. To achieve the company's goals, superior human resources are needed in order to achieve performance as expected by the company, as well as in cleaning service companies that have strong competitiveness. The development of cleaning services has 
experienced a fairly good increase, where during the current pandemic everyone is doing activities at home. There are also not many employees who work in the office so that these activities require that the condition of the home or office must always be clean and comfortable to improve employee performance. There are several factors that affect employee performance including Self Ability, Compensation, and Self Efficacy.

The success of Company is not only achieved by implementing a business plan but must be supported by the company's human resources (Candraningrat, C., et al, 2018). If the human resources in the company have achieved their goals, it can be said that the company has the power to compete with other companies. Seeing some of the phenomena above, the problems in this research can be formulated: Do Self Ability, Compensation and Self Efficacy affect employee performance of Rizqy Jaya Mulia company.

\section{Research Methods}

Research design: This study uses quantitative methods to measure the effect of Self Ability, Compensation, and Self Efficacy on the performance of employees of Rizqy Jaya Mulia Company. Where the population taken as respondents are all employees in the company by involving all employees as samples in the study or the total population sample. While the type of data used in this study is quantitative and the source of data used is primary data obtained directly from respondents through survey techniques with questionnaire instruments arranged on a Likert scale of 1-5 from Disagree to Strongly Agree. While the Data Analysis Techniques used were Validity Test, Reliability Test to test the reliability and consistency of the instruments used, besides that, Classical Assumption Test was carried out as a condition for using analysis tools in the form of Multiple Regression Analysis to determine the magnitude of the influence of each relationship between variables. Furthermore, hypothesis testing is carried out using the F-test and t-test and determination analysis is carried out through SPSS version 25.

\section{Result and Discussion}

1. Theoritical Framework

a. Work Ability

Employee self-ability is a person's ability to complete work within a certain time (Eva Rachmawati et al. 2018). Meanwhile, according to Hamzah Uno (2010), self-ability is a character that arises from someone who is related to effective and superior performance in a job. In the research of Raharjo, Paramita \& Warso (2016) indicators of self-ability include knowledge; Training; Experience; Skills and ability to work. Employee ability or self-ability has an effect on employee performance as stated by Nuriasih (2016), Wicaksono (2017) and Eva Rahmawati from the results of their research stating that work ability has a significant effect on employee performance, as well as the results of Auw's research, Charolina Mutiasari Lukito (2016) that self-ability has a positive and significant effect on employee performance, this means that with good abilities, employees will be able to complete their work well. Self- efficacy is selfconfidence of employees on their ability to complete their work, and high self-efficacy can improve employee performance as stated by Kaswan (2011:30), and Ance Selfi 
Adianita, et al. (2018) that if employees have high self-efficacy, they get high performance as well.

\section{b. Compensation}

Compensation is all income in the form of money, direct goods or indirect goods, which are received by employees as compensation and services provided to the company (Mujanah, 2019). Meanwhile, according to Hasibuan (2013: 118), compensation is all income in the form of money, goods directly or indirectly received by employees in return for services provided to the company. The compensation indicators according to Simamora (2014: 445) are wages and salaries, incentives, and benefits. Simamora (2014: 461) distinguishes compensation into two types, namely direct compensation and indirect compensation: 1) Direct Compensation, consisting of: Salary, Incentives, Bonus 2) Indirect Compensation, consisting of all financial rewards not included in direct compensation. From the definition of compensation above, it is concluded that compensation is all income or income in the form of money or objects directly or indirectly given to employees by the company as a reward for services that have been achieved by employees with the ability the maximum.

The right compensation system can improve employee performance, this is in accordance with the results of his research by Widiartanto (2019), which states that compensation has a significant effect on employee performance. Thus, it can be said that appropriate compensation can improve employee performance.

\section{c. Self Efficacy}

In addition of self-ability, performance is also influenced by self-efficacy, which is an assessment of one's beliefs whether one can successfully learn knowledge or skills (Kaswan, 2011). Self efficacy is an assessment of one's beliefs about whether a person can successfully learn a knowledge or skill.Self- efficacy is a determinant of learning readiness. Trainees who have self-high efficacy can carry out various ways of learning in exercise program and more inclined to persist in learning despite environmental influences that are not conducive to it" Kaswan (2011).

Self-efficacy can also be interpreted as a determinant in learning readiness. Trainees who have high self-efficacy can implement various ways to learn in the training program and always insist on learning despite the influence of an unfavorable environment. Ance Selfi Adianita, et al. (2018), it is further said that the dimensions of self-efficacy are magnitude or level, strength, generality. According to Herman Hidayat, Ivan Aries Setiawan (2016), in the study stated that high Self Efficacy can increase high employee performance as well, this is also supported by Putra Setiawan, and Tri Andjarwati (2017), in the study stated that Self Efficacy has an effect on significant to employee performance.

d. Performance

Thus, some research results state that performance is influenced by Self ability, Compensation, and Self Efficacy. According to Mangkunegara (2013), performance is the result of work in quality and quantity achieved by an employee in completing his work according to the responsibilities given to employees. Meanwhile, according to Kasmir (2016) that performance is the result of work and work behavior that has been achieved in completing the tasks and responsibilities given in a certain period. Meanwhile, 
according to Wilson Bangun (2012:34), the measures of performance indicators are grouped into five categories, including quantity of work, quality of work, punctuality, attendance and ability to work together.

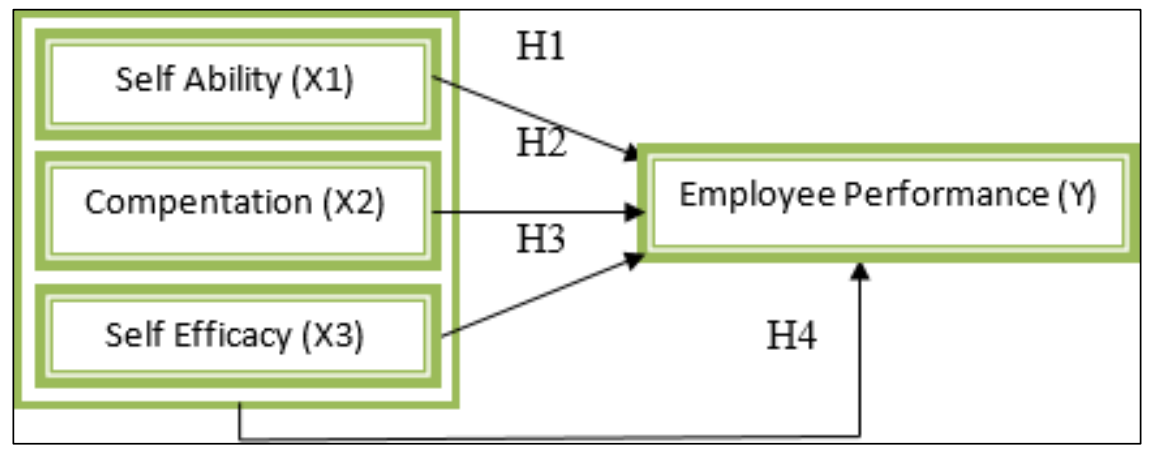

Figure 1. Theoretical Frameworks

Figure 1 shows that the conceptual framework in this study is to show a causal relationship or influence between the variables Self ability, Compensation and Self Efficacy on employee performance.

2. Hypothesis

Based on the conceptual framework in Figure 2, the following hypotheses can be formulated, among others:

- H1: Self Ability has a significant effect on the performance of employees of PT. Rizqy Jaya Mulia Sidoarjo.

- H2: Compensation has a significant effect on the performance of employees of PT. Rizqy Jaya Mulia Sidoarjo.

- H3: Self Efficacy has a significant effect on the performance of employees of PT. Rizqy Jaya Mulia Sidoarjo

- H4: Self Ability, Compensation, and Self Efficacy simultaneously affect the performance of employees ofPT. Rizqy Jaya Mulia Sidoarjo

Validity Test and Reliability Test: An instrument can be said to be valid if it can measure what is desired and produce data from the variables studied appropriately. The assessment of the validity test in this study is to compare the calculated $r$ value with the $r$ table value at a significance of 0.05 with a 2-sided test and the amount of data $(n)=45$, $\mathrm{df}=\mathrm{n}-2$ then $\mathrm{df}=45-2=43$ obtained $\mathrm{r}$ table of 0.301 . So the value of $\mathrm{r}$ count $>\mathrm{r}$ table which indicates that all questions in the questionnaire are declared valid. The reliability test was conducted to determine the consistency of respondents' answers in answering questions that could measure the variables in this study. A variable can be said to be reliable if the Cronbach's Alpha value $>0.70$ so that every question that makes up each variable in this study is declared reliable.

Multiple Regression Analysis Test: Before computing multiple regression analysis the Classic assumption test should analysis its contents of Normality, Multicolliniarity and Heterocedasticity. The results of this test as follows: Normality Test; the result of this test shows that the residual is normally distributed if the significance value is $>0.05$. The results of the normality test analysis show that the 
significance value is $0.200>0.05$, so it can be concluded that the residual value is normally distributed.

The second Multicollinearity Test; it is done by looking at the VIF value of each independent variable, if the VIF value is $<10$, it can be concluded that the data is free from multicollinearity symptoms (Imam Ghozali, 2011:105). The results of the analysis of the Multicollinearity Test showed that the VIF value for all variables was $<10$, so it can be said that the data in this study were free from multicollinearity symptoms.

The tirds is Heteroscedasticity Test; Heteroscedasticity Test aims to test whether in the regression model there is an inequality of variance from one observation residual to another observation. The results of the analysis of the Heteroscedasticity Test show that the points spread below the number 0 on the $Y$ axis or do not form a certain pattern. So it can be concluded that the data proved that there was no heteroscedasticity.

Regression analysis was used to determine the effect of the variables Self Ability, Compensation, and Self Efficacy on the performance of employees of PT. Rizqy Jaya Mulia Sidoarjo.

Table 1 Multiple Linear Regression Results

\begin{tabular}{|c|c|c|c|c|c|c|}
\hline \multicolumn{7}{|c|}{ Coefficient $^{\mathrm{a}}$} \\
\hline & \multirow{2}{*}{ Model } & \multicolumn{2}{|c|}{$\begin{array}{l}\text { Unstandardized } \\
\text { Coefficient }\end{array}$} & \multirow{2}{*}{$\begin{array}{c}\text { Standardized } \\
\text { Coefficient } \\
\text { Beta }\end{array}$} & \multirow{2}{*}{$\mathbf{t}$} & \multirow{2}{*}{ Sig } \\
\hline & & B & Std. Error & & & \\
\hline \multirow[t]{4}{*}{1} & Constant & ,129 & 4,003 & & ,032 & ,974 \\
\hline & Self Ability (X1) & ,339 & ,162 & ,317 & 2,096 & ,042 \\
\hline & Compensation (X2) &, 548 & ,253 & ,317 & 2,165 & ,036 \\
\hline & Self Efficacy (X3) & 481 & ,227 & ,282 & 2,12 & ,04 \\
\hline
\end{tabular}

a. Dependent Variable : Employee performance (Y)

(Source : Primary data processed, 2021)

The results of these calculations, the Multiple Linear Regression equation for this study is obtained:

$$
\mathrm{K}=0,129+0,339 \mathrm{~A}+0,548 \mathrm{KO}+0,481 \mathrm{E}+\mathrm{e}
$$

From the results of the multiple linear regression equation above, it can be interpreted as follows:

a. The constant of 0.129 has a positive value indicating that the independent variables Self Ability, Compensation, and Self Efficacy are fixed or constant, then the variation of changes in the dependent variable employee performance tends to be positive.

b. The coefficient of the Self Ability variable is positive. This means that the Self Ability variable has a positive influence on employee performance with the acquisition value of 0.339 with the assumption that the other variables are fixed or constant. Thus it can 
be said that if the self-ability possessed by the employee increases, the employee's performance will increase.

c. The coefficient of the compensation variable is positive. This means that the compensation variable has a positive influence on the employee performance variable, with a value of 0.548 assuming the other variables are fixed or constant. This shows that if the compensation given to the employee is increased, the employee's performance will also increase.

d. The coefficient of the Self Efficacy variable is positive. This means that the Self Efficacy variable has a positive influence on employee performance, with the acquisition value of 0.481 with the assumption that the other variables are fixed or constant. This means that if the employee's self-efficacy increases, the employee's performance will also increase.

Hypothesis test: to find out that the variables of Self Ability, Compensation, and Self Efficacy have a simultaneous effect on employee performance, it is necessary to have a statistical test F-test (Simultaneous). The following are the results of the F-test statistical test in table 4.9 as follows:

Table 2 Hypothesis Testing Results with F Test

\begin{tabular}{|c|c|c|c|c|c|c|}
\hline \multicolumn{7}{|l|}{ ANOVA $^{a}$} \\
\hline & Model & $\begin{array}{l}\text { Sum of } \\
\text { Squares }\end{array}$ & Df & Mean Square & $\mathbf{F}$ & Sig. \\
\hline \multirow[t]{3}{*}{1} & Regression & $1.330,53$ & 3 & 443,51 & 30,937 &, $000^{\mathrm{b}}$ \\
\hline & Residual & 587,781 & 41 & 14,336 & & \\
\hline & Total & $1.918,31$ & 44 & & & \\
\hline
\end{tabular}

a. Dependent Variable Employee performance

b. Predictors (Constant), Self Efficacy (X3), Compensation (X2), Self Ability (X1)

(Source : Primary data processed, Author (2021))

In the F-test, the F-count value is 30.937 , this value is greater than the f-table, namely 3.22 or $\mathrm{f}$ - count $30.937>\mathrm{f}$-table 3.22 with a probability value of $0.000<0.05$ so that the regression model can be used to predicting employee performance variables or it can be said that the variables Self Ability, Compensation, and Self Efficacy together (simultaneously) have a significant effect on employee performance.

$t$-test was conducted to compare the $t$-count with the $t$-table at a significance level of $=0.05$. If the $t$-count is greater than $t$-table ( $t$-count $>t$-table ) or the probability of error is less than $5 \%(\operatorname{sig}<0.05)$, then it can be stated that $\mathrm{X} 1, \mathrm{X} 2$ and $\mathrm{X} 3$ have an effect on $\mathrm{Y}$. The results $t$ test can be seen in table 3 . 
Table 3 Results of Hypothesis Testing with t Test

\section{Coefficient $^{\mathrm{a}}$}

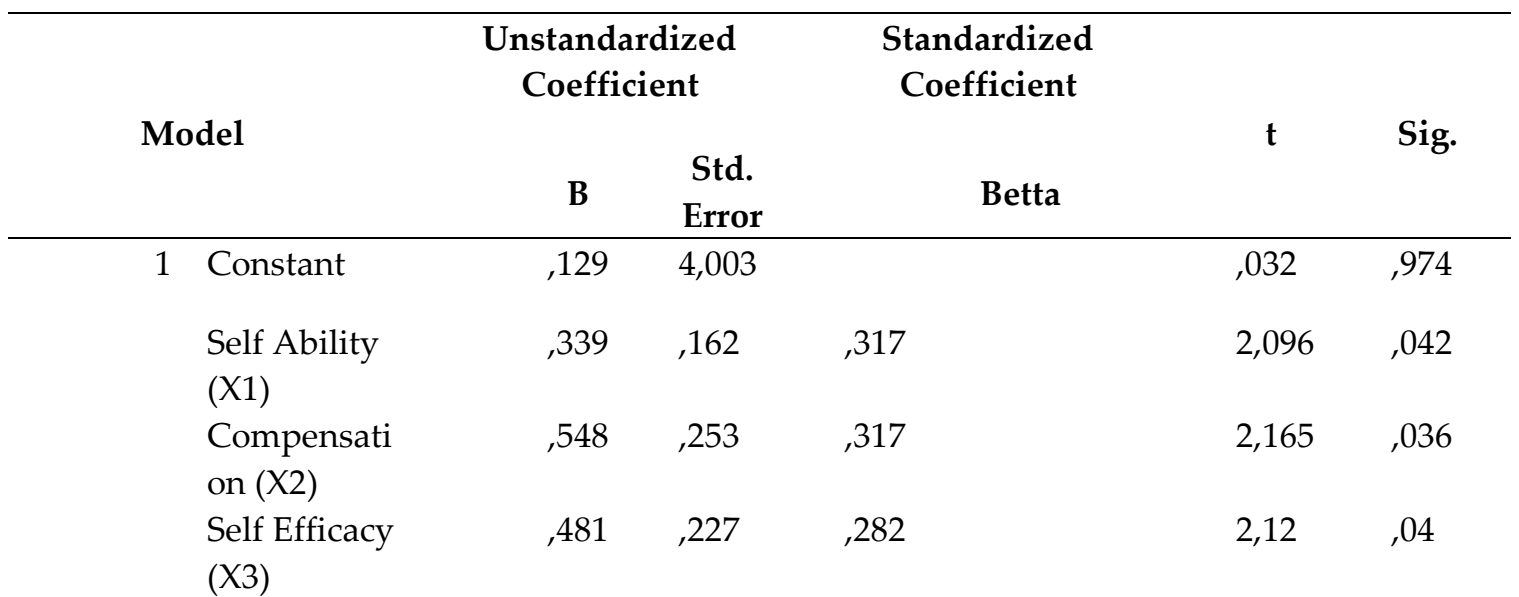

a. Dependent Variable : Employee performance $(\mathrm{Y})$

(Source : Primary data processed, Author (2021))

The results of the t-test analysis in the table above are as follows :

a. The Self Ability variable has a t-count value of $2.096>2.018$, so it is stated that $t$-count $>$ t-table. The significance value is $0.042<0.05$. So it can be concluded that the hypothesis (H1) is accepted, meaning that Self Ability has a significant effect on employee performance.

b. The Compensation variable obtains a t-count value of $2.165>2.018$, so it is stated that $\mathrm{t}$-count $>\mathrm{t}$-table. The significance value is $0.036<0.05$. So it can be concluded that the hypothesis (H2) is accepted, meaning that compensation has a significant effect on employee performance.

c. The Self Efficacy variable obtains a t-count value of $2.120>2.018$, so it is stated that $t-$ count $>\mathrm{t}$ - table. The significance value is $0.040<0.05$. So it can be concluded that the hypothesis (H3) is accepted, meaning that Self Efficacy has a significant effect on employee performance.

Coefficient of Determination (R2): The coefficient of determination (R2) aims to measure how far the regression model's ability to explain the variables of Self Ability, Compensation, and Self Efficacy on employee performance. The value of the coefficient of determination is determined by looking at the Adjusted $R$ Square value as can be seen in table 4 below:

Table 4 Coefficient of Determination Test Results

Model Summary ${ }^{\mathrm{b}}$

Model R R Square Adjusted R Square $\begin{array}{r}\text { Std. Error of } \\ \text { theEstimate }\end{array}$

$10,833^{\mathrm{a}} \quad 0,694 \quad 0,671 \quad 3,786$




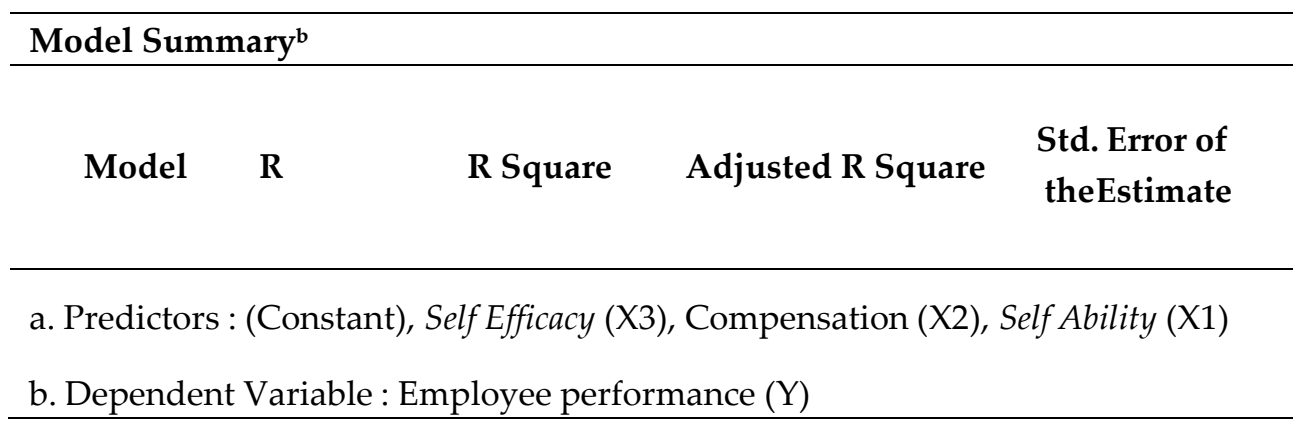

(Source: Primary data processed, 2021)

Based on table 4 above, the coefficient of determination of Adjusted R square is 0.671. This shows that $67.1 \%$ of the variables of Self Ability, Compensation, and Self Efficacy affect the variable of Employee Performance. As for the remaining 32.9\% influenced by other variables outside of this study.

Discussion of Research Results: The results of the data analysis have been processed if all items are proven to be valid and reliable. Not only that, the results of the analysis also prove that the data are normally distributed, and the data does not show symptoms of multicollinearity and heteroscedasticity.

a. The Effect of Self Ability on Employee Performance

Based on the results of the analysis, it can be seen from the significance value of $0.042<0.05$, so it is declared positive. In addition, the results of the linear regression analysis and the regression coefficient which show a value of 0.339 are positive. If the Self Ability variable increases by one unit, then the value of the Employee Performance variable will increase by 0.339 with the assumption that the other independent variables are fixed or constant. This shows that partially has a significant influence between Self Ability on employee performance. The results of this study support the results of research by Eva Rachmawati, Siti Mujanah, and Wiwik Retnaningsih (2018) which states that the variable employee ability has a positive and significant effect on employee performance. So the results of this study can be concluded that Self Ability has a positive and significant effect on employee performance.

b. The Effect of Compensation on Employee Performance

Based on the results of the analysis, it can be seen from the significance value of $0.036<0.05$, then it is declared positive. In addition, the results of linear regression analysis and regression coefficients which show a value of 0.548 are positive. If the compensation variable increases by one unit, the value of the Employee Performance variable will increase by 0.548 with the assumption that the other independent variables are fixed or constant. This shows that partially has a significant influence between compensation on employee performance. The results of this study support the results of Auw's research, Charolina Mutiasari Lukito (2016) which states that the compensation variable has a positive and significant effect on employee performance. So in this study it can be concluded that compensation has a positive and significant effect on employee performance.

c. The Influence of Self Efficacy on Employee Performance

Based on the results of the analysis, it can be seen from the significance value of $0.040<0.05$, so it is declared positive. In addition, the results of linear regression analysis 
and regression coefficients which show a value of 0.481 are positive. If the Self Efficacy variable increases by one unit, then the value of the Employee Performance variable will increase by 0.481 with the assumption that the other independent variables are fixed or constant. This shows that partially has a significant influence between Self Efficacy on employee performance. The results of this study support the results of their research by Akhir Putra Setiawan and Tri Andjarwati (2017) which states that there is a positive and significant influence on self-efficacy on employee performance. So in this study it can be concluded that Self Efficacy has a positive and significant effect on employee performance.

d. The Influence of Self Ability, Compensation, and Self Efficacy on Employee Performance

Based on the results of the study and several tests, it can be seen that the significance value in the $F$ test is $0.000<0.05$, this proves that the regression model in this study has a significant positive value and is declared feasible to explain the effect of the variables Self Ability, Compensation, and Self Efficacy on Employee Performance. The calculated $F$ value is 30.937 while the $F$ table value $=3.22$ because the calculated $F$ value is $30.937>3.22$, then as the basis for decision making in the F test it can be concluded that Ho is rejected and Ha is accepted. These results indicate that Self Ability, Compensation, and Self Efficacy simultaneously affect the Employee Performance of PT. Rizqy Jaya Mulia Sidoarjo.

\section{Conclusion}

Based on the results of research on the effect of Self Ability, Compensation, and Self Efficacy on employee performance at Rizqy Jaya Mulia Company, Sidoarjo. So the conclusion of this study is that Self Ability has a significant effect on Employee Performance, Compensation has a significant effect on Employee Performance, Self Efficacy has a significant effect on Employee Performance and Self Ability, Compensation, and Self Efficacy simultaneously have a significant effect on Employee Performance.

Based on the conclusions above, the implication of this research is that if the company will improve employee performance, it is necessary to optimize Self Ability, Compensation, and Self Efficacy by paying attention to the performance of its employees and giving an award for skills, work performance, etc. Because in essence employee performance is very important for the company and can affect the results of employee work. For further researchers, it is hoped that they can add or involve several other variables that can affect employee performance that have not been studied in this study.

\section{References}

[1] A.A Anwar Prabu Mangkunegara. 2013. Manajemen Sumber Daya Manusia Perusahaan. Bandung: PT. Remaja Rosda Karya.

[2] Adianita, Ance Selfi; Siti Mujanah; Candraningrat. 2017. "Kompetensi Karyawan, Emotional Quotient dan Self Efficacy Pengaruhnya terhadap Organizational Citizenship Behavior dan Kinerja Karyawan pada Indomobil Grup di Surabaya". 
Jurnal Riset Ekonomi Dan Manajemen Volume 17, No. 1, Januari - Juni (Semester I) 2017.

[3] Auw, Charolina Mutiasari Lukito, 2016. Pengaruh Kemampuan Dan Kompensasi Terhadap Kinerja Karyawan Perusahaan Plastik Putera Di Gombong, Jawa Tengah. AGORA Vol. 4, No. 1.

[4] Bangun, Wilson 2012. Manajemen Sumber Daya Manusia. Jakarta : Penerbit Erlangga.

[5] Candraningrat, C., Oktaviani, O., \& Suhandiah, S. (2018). Analysis of the success factors for MSME succession in Surabaya: A principal component analysis. Journal of Economics, Business, and Accountancy Ventura, 21(2), 207-217.

[6] Ghozali, Imam. 2011. Aplikasi Analisis Multivariate Dengan Program SPSS. Semarang: Badan Penerbit Universitas Diponegoro.

[7] Hamzah B. Uno, M. (2010). Teori Motivasi Dan Pengukurannya. Jakarta: PT Bumi Aksara.

[8] Karya, D. F., \& Rasyid, R. A. Candraningrat, (2020) C The Effect Of Work Interfere Family And Family Interfere Work On Commitments Through Satisfaction And Motivation. Business and Finance Journal

[9] Kasmir. 2016. Manajemen Sumber Daya Manusia (Teori dan Praktik). Depok: PT Rajagrafindo Persada. Kaswan M. M. 2011. Pelatihan dan Pengembangan untuk meningkatkan kinerja SDM. Bandung:CVAlfabeta.

[10] Rachmawati, Eva; Siti Mujanah dan Wiwik Retnaningsih, 2018. Pengaruh Self Leadership, Kecerdasan Sosial, Employee Ability Terhadap Komitmen Organisasional dan Kinerja Karyawan Dinas Pengendalian Penduduk, Pemberdayaan Perempuan dan Perlindungan Anak Kota Surabaya. JMM17 Jurnal Ilmu Ekonomi \& Manajemen. Vol. 05, No. 02.

[11] S.P,Hasibuan, Malayu. 2013. Manajemen Sumber Daya Manusia. Jakarta: PT. Bumi Aksara

[12] Setiawan, Akhir Putra dan Tri Andjarwati 2017. "Pengaruh Self Efficacy Dan Motivasi Terhadap Kinerja Karyawan Pt. Busson Auto Finance (BAF) Cabang Surabaya I". JEM17 Jurnal Ekonomi Manajemen, Hal 275 - 284. Volume 2, Nomor 1, Mei 2017

[13] Simamora, Henry. 2014. Manajemen Sumber Daya Manusia. Yogyakarta: Bagian Penerbitan Sekolah Tinggi Ilmu Ekonomi YKPN

[14] Siti Mujanah. 2019. Manajemen Kompensasi. Surabaya: CV. Putra Media Nusantara (PMN).

[15] Subekhi Akhmad, Mohammad Jauhari. 2012. Pengantar Manajemen Sumber Daya Manusia. Jakarta : Pustaka Karya

[16] Sugiyono. 2017. Metode Penelitian Kuantitatif, Kualitatif, dan R\&D. Bandung: CV. Alfabet 